\title{
Alpine Strawberry as a Potential Niche Crop for Florida Growers and Homeowners'
}

\author{
Alan H. Chambers ${ }^{2}$
}

\section{Abstract}

Alpine strawberries (Fragaria vesca) are known for their excellent eating quality but are much less cultivated than the common commercial strawberry. Alpine strawberries have small ( $\sim 1$ gram) red or yellow fruit that are too soft for long-distance transport. This could create opportunities for local and niche fruit production. Many named Alpine strawberry varieties are available through online vendors, but key information like yield potential and differences in eating quality are unknown. This article describes yield and fruit quality results to guide variety selection for potential growers. Top yielding varieties grown in southern Florida were 'Baron Solemacher' and 'Reine des Vallees' for redfruited types, and 'White Delight' and 'White Solemacher' for white-fruited types. There were no significant fruit quality differences among the varieties tested. The results of this project are anticipated to benefit growers and homeowners looking to cultivate specialty Alpine strawberries.

\section{Introduction}

Alpine strawberries (Fragaria vesca) produce edible and highly aromatic strawberries that might provide a niche opportunity for growers and homeowners in Florida. F. vesca is known by many common names, including Alpine strawberry, diploid strawberry, wild strawberry, and gourmet strawberry. The fruit are small ( 1 gram) and are prized for their intense aroma and soft texture. The berries are fragile and are not suitable for long-distance shipping.
This might inhibit trade on the international market but also provides an opportunity for growers catering to local markets and homeowners that are interested in something deliciously unique.

Alpine strawberries grow wild throughout the northern hemisphere. There is only limited commercial production in parts of Europe and some seed-based production in the United States for online vendors. Alpine strawberries are a summer favorite in temperate regions but could grow well in Florida depending on the growing season. The compact bushes can be propagated by seed, runners, and/or crowns. There are both red-fruited and white-fruited types. Alpine strawberries have been heavily researched due to their favorable aroma, but little has been done to measure their yield potential. This is especially true for growing in a subtropical environment where winter production would be favorable in contrast to summer production in temperate regions. Interestingly, this species also serves as a proxy for research on the commercial strawberry because it has a sequenced genome and rapid generation cycle.

As part of the University of Florida Institute of Food and Agricultural Sciences, we undertook a project to test Alpine strawberry varieties as a potential niche crop for Florida. Our primary objectives were to measure yield and fruit quality so growers and homeowners would be better informed when selecting Alpine strawberry varieties to grow. This research will also bring more visibility to a crop that is largely unknown in the United States. While these

1. This document is HS1326, one of a series of the Horticultural Sciences Department, UF/IFAS Extension. Original publication date February 2019. Visit the EDIS website at https://edis.ifas.ufl.edu for the currently supported version of this publication.

2. Alan H. Chambers, assistant professor, Horticultural Sciences Department; UF/IFAS Tropical Research and Education Center, Homestead, FL 33031

The Institute of Food and Agricultural Sciences (IFAS) is an Equal Opportunity Institution authorized to provide research, educational information and other services only to individuals and institutions that function with non-discrimination with respect to race, creed, color, religion, age, disability, sex, sexual orientation, marital status, national origin, political opinions or affiliations. For more information on obtaining other UF/IFAS Extension publications, contact your county's UF/IFAS Extension office. 
results specifically apply to southern Florida, other regions may easily apply these learnings to their own growing regions.

\section{Selecting Named Varieties}

There are many named Alpine strawberry varieties. An internet search will identify a number of potential seed vendors. The varieties tested in this paper were chosen based on fruit color, availability, and some prior knowledge about the different qualities of each. These included red-fruited types 'Alexandria, 'Ali Baba, 'Attila, 'Baron Solemacher', 'Bowlenzauber, 'Fragolina di Bosco, 'Mignonette, 'Quattro Stagioni,' 'Reine des Vallees, 'Reugen', and 'Semperflorens', and white-fruited types 'Golden Alpine,' 'Ivory', 'White Delight', and 'White Solemacher'. Picking a few types based on fruit color and the information in this document is a good place to start when growing Alpine strawberries for the first time. An example of the Alpine strawberry plant is shown in Figure 1. The red and white fruit types are shown in Figure 2. Raised beds covered with plastic mulch were used in this study to control weeds, but other practices including plant-based mulches could also be used.

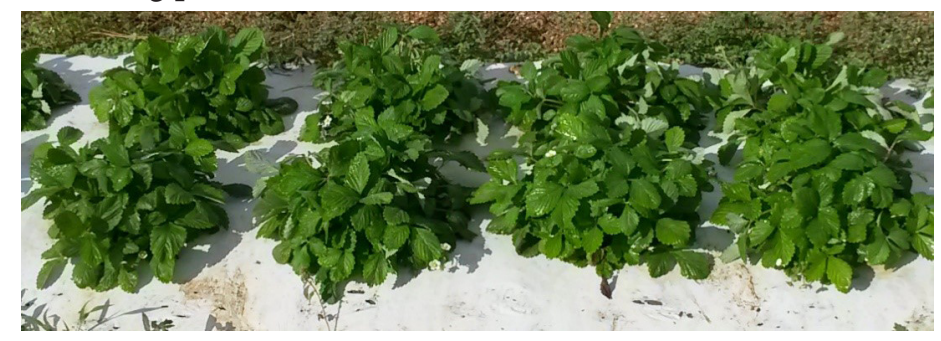

Figure 1. Alpine strawberry plants shown in two rows with 15-inch spacing between plants. In general, the leaves are lighter green and thinner than common strawberry plants. The flowers and fruit are also smaller than common strawberry.

Credits: Alan H. Chambers, UF/IFAS

\section{Growing Alpine Strawberries}

Alpine strawberry plants are fairly robust, though care must be taken during the initial stages of growth. Seeds are the most common means to propagate different varieties. Seeds should be kept cool and dry until sowing. Most common soilless mixes or growth substrates available at local garden or hardware stores are suitable for starting seeds. Four-inch pots are a good size for starting seeds. Seeds should be directly sown on top of a watered substrate. Usually, only a few seeds per pot are needed. Some advocate for vernalizing (exposing seeds to cold but non-freezing temperatures) seeds in a fridge for a week, though this may not be necessary depending on the age of the seed and previous storage conditions. Once removed from vernalization, healthy seeds will germinate in 10-14 days at room temperature. Care should be taken so seeds and seedlings do not dry out. This can be accomplished using humidity domes or with regular spritzing with tap water. Like most plants, overwatering will negatively impact seedling growth.

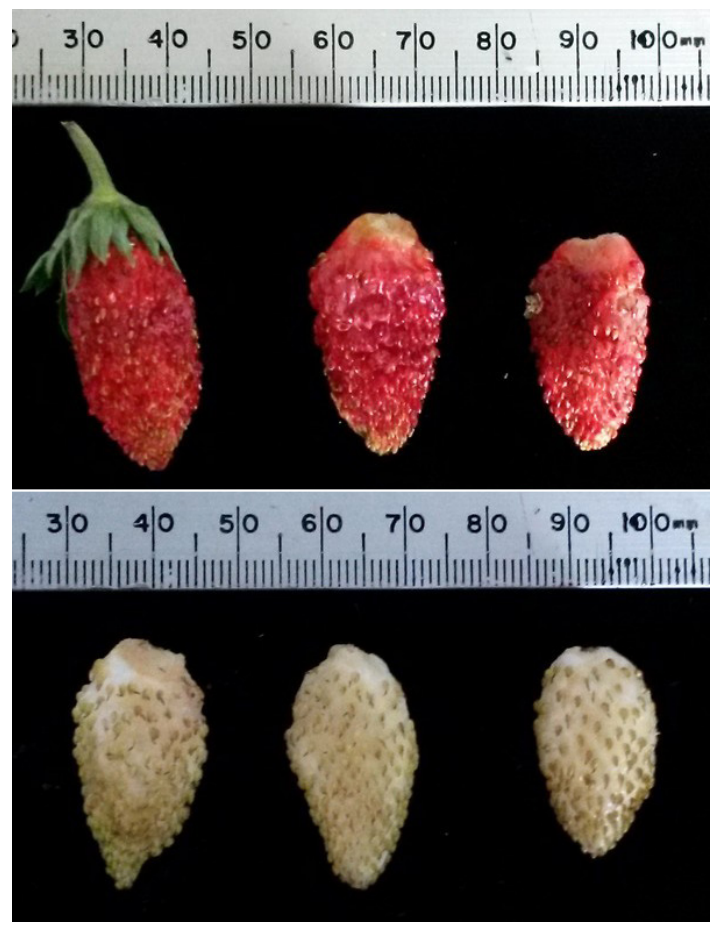

Figure 2. Examples of red and white Alpine strawberry fruit types. Some varieties are naturally calyx-free when harvested. Note: $25 \mathrm{~mm}$ is $\sim 1$ inch.

Credits: Alan H. Chambers, UF/IFAS

Germinated seeds require direct sunlight and regular watering to thrive. A slow-release fertilizer will accelerate plant development. Plants can be sown outside when they are a few inches tall and after all danger of frost is past in your growing regions. In southern Florida, sowing seeds in July for transplanting from October to November works well. In other parts of Florida, seeds should be sown a few months prior to transplanting in the early spring or early fall. Plants will begin flowering a few months after transplanting and fruit will rapidly develop. Alpine strawberry plants do not require chilling in order to flower and fruit, and will continue producing fruit until summer heat transitions the plants to primarily vegetative reproduction. Eventually, increasing summer temperatures will lead to plant decline and death by mid-summer.

Fruit should be picked when fully ripe because they will not develop full flavor and aroma if picked too early. Color, aroma, and firmness are all cues to determine when the fruit are ripe. Red-fruited types will turn completely red, will be deliciously aromatic, and will become soft. Whitefruited types will turn from white to yellow and will also be highly aromatic and soft. Fruit should be picked regularly, and the plants will continue to fruit throughout the season 
as long as the plants are healthy and supplied with the proper nutrients, water, and sunlight.

Many Alpine strawberries can be also be propagated by runners or crown division. The propensity to runner is a genetic trait, and varieties can be selected that do not runner. Most seed sources will detail if the accessions for sale are capable of producing runners. Runners can be rooted either near the mother plant in native soil or in four-inch pots with soilless mix. Runners will typically only take a few weeks to fully establish a healthy root system. Runners can be severed from the mother plant once rooted. Crown division is necessary for non-runner types. To split strawberry crowns, the entire plant is removed from the soil and the crowns are separated manually by pulling them apart. Crowns with intact roots will establish at higher rates and recover faster from division.

\section{Disease}

This preliminary yield-evaluation study was designed with minimal inputs to test for robustness of the selected varieties. No pesticides were applied in this study except for a single application of snail bait to control snails at the beginning of the season. Disease pressure was light during the regular growing season and major pathogen problems did not manifest until later in the season as temperatures increased well past the productive season for the plants.

\section{Yield}

More is better whether you are growing Alpine strawberries commercially or for fun. We tested sixteen varieties of Alpine strawberries to measure which produced the most fruit over a short growing season. The results from the best red-fruited and white-fruited types are shown in Figure 1. Harvesting occurred twice each week starting on January 19, 2017. Figure 3 shows two of the top-yielding red types ('Baron Solemacher' and 'Reine des Vallees') and two of the highest-yielding yellow types ('White Delight' and 'White Solemacher'). Yield results for each accession are shown in Table 1. This includes average plot yield, average plot number, and average total plot yield over the trial growing season (in grams or pounds) for each accession.

It is anticipated that total yield could be increased by planting earlier in the fall season. Early establishment could increase the length of the harvest season, as Alpine strawberries will continue to flower and fruit under the appropriate environmental and cultural conditions. Lateseason yield will decrease as increasing temperatures lead to vegetative growth and a reduction in flowering.

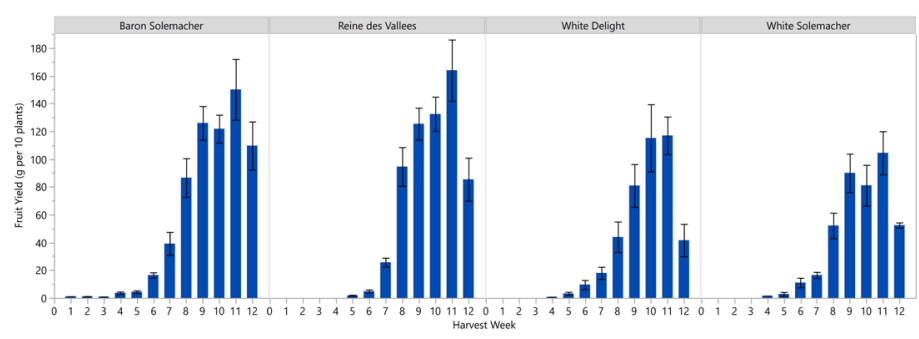

Figure 3. Yield for four Alpine strawberry varieties over 12 weeks of fruiting. Results are averages from three plots of ten plants each. Note: $\sim 110$ grams $=0.25 \mathrm{lbs}$.

\section{Fruit Quality}

Alpine strawberries are highly aromatic compared to common strawberries. Major differences in fruit quality attributes like sweetness (Figure 4), acidity (Figure 5), aroma (Figure 6), and Brix/acid ratio (Figure 7) could impact the overall desirability of the product. Our work measured each of these important traits and found that the varieties were very similar from a fruit quality perspective. Therefore, selection of the highest-yielding varieties would be the major driver of economic returns for the varieties tested.

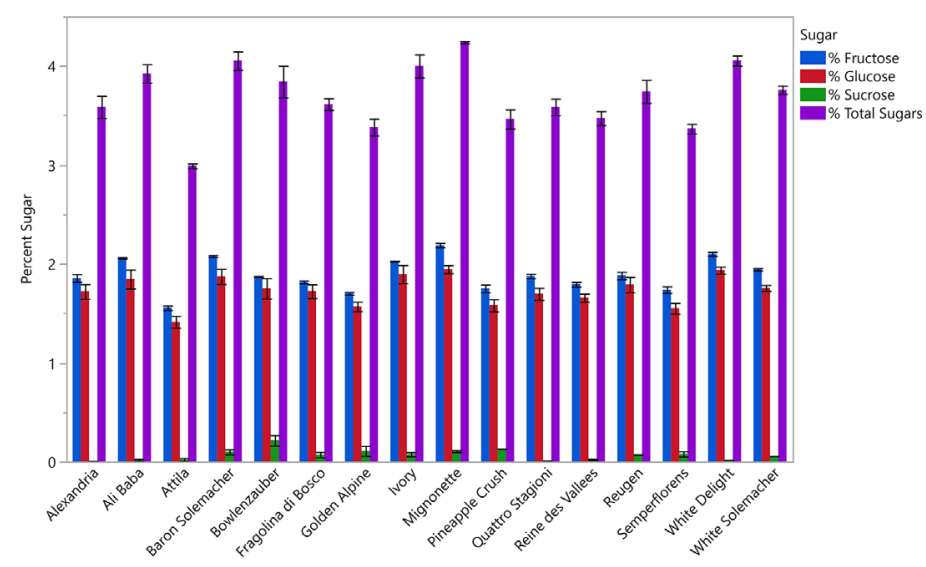

Figure 4. Sugar content of sixteen Alpine strawberry varieties. There is most likely no real difference in the sweetness of these varieties when tasted.

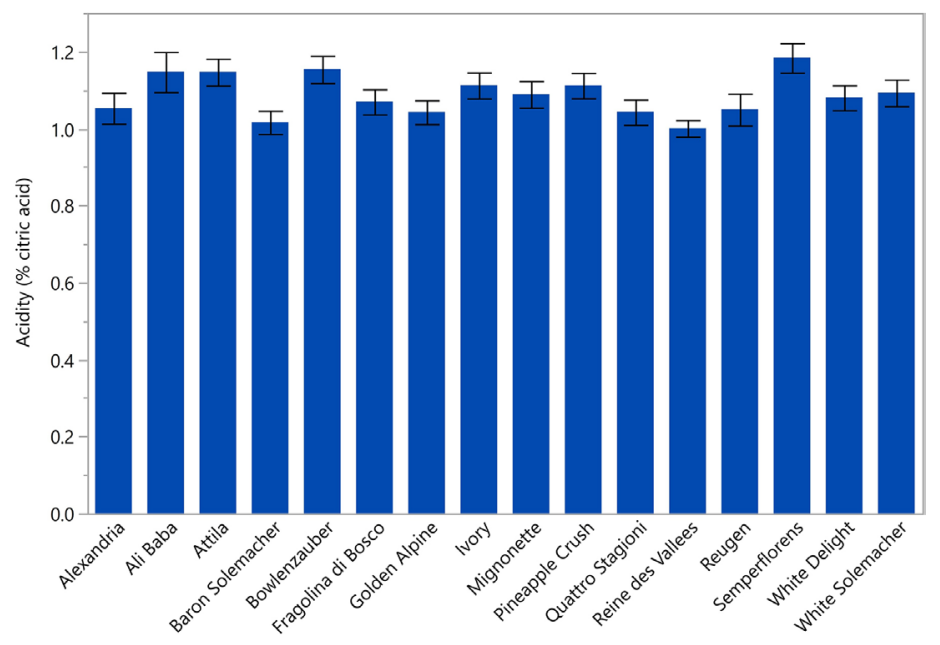

Figure 5. Acidity levels of sixteen Alpine strawberry varieties. There is most likely no real difference in the acidity of these varieties when tasted. 


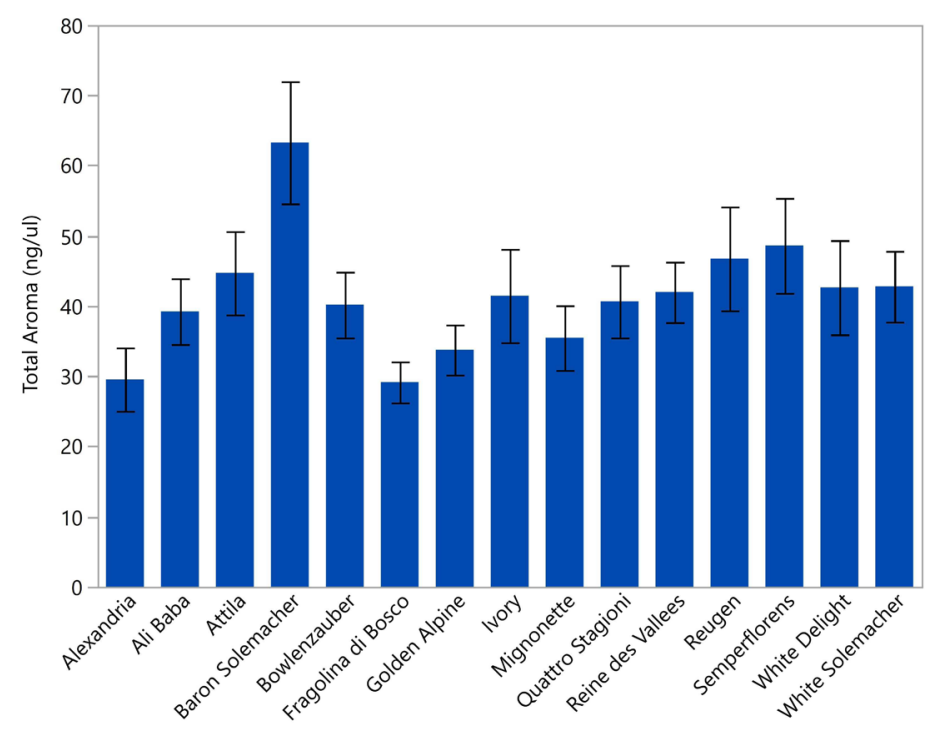

Figure 6. Total aroma content of sixteen Alpine strawberry varieties. Not all aroma compounds included in this data will have sensory impacts, but accessions with higher total aroma may be increasingly desirable. The similarities across all accessions suggest that aroma should not be a major reason to select one accession over another.

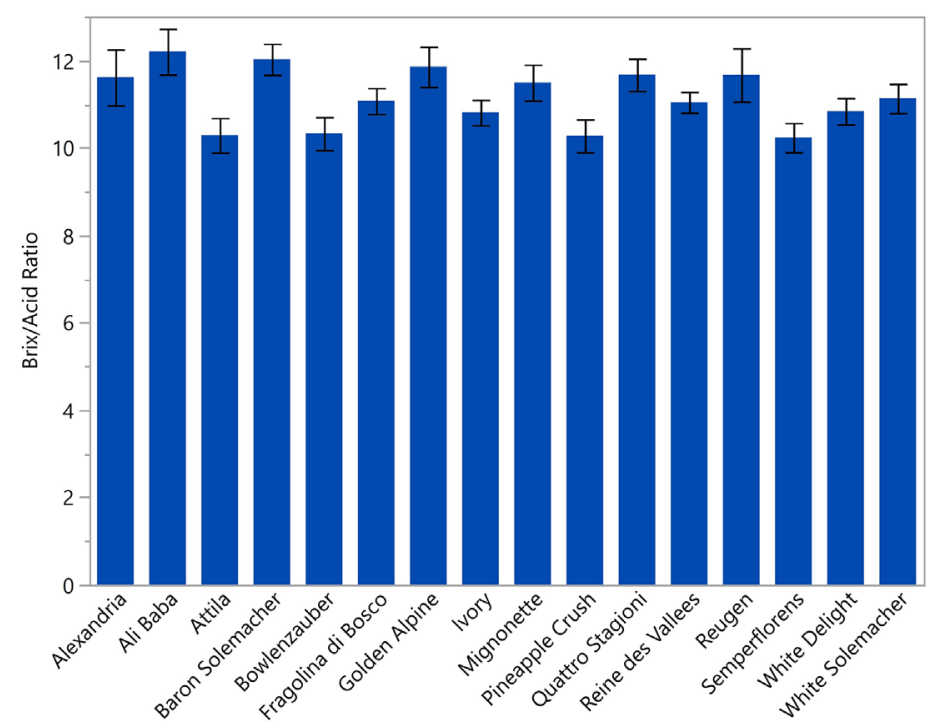

Figure 7. Brix-to-acid ratio for sixteen Alpine strawberry varieties. There were no significant differences among varieties for Brix-to-acid ratio.

\section{Potential Market Opportunities}

The potential market opportunities for Alpine strawberries in the United States are unknown. Limited production in Europe is focused on local, gourmet markets. Alpine strawberries are an attractive crop for a number of reasons. The fruit itself looks like a strawberry, although a smaller version of what consumers are used to seeing. The external aroma of the fruit can also entice buyers at a distance. This species is also quick to yield product and could be inexpensive to maintain. They could possibly be marketed as "mini" or "baby" strawberries."
There are also many unknowns for domestic Alpine strawberry production. Demand, consumer willingness to pay, economic comparison to growing common strawberry, and other factors will all contribute to the market potential for this species.

\section{Conclusions}

Alpine strawberries are a highly aromatic and desirable fruit that are largely unknown commercially in the United States. Opportunities for Florida growers include niche and local markets during the winter season. The overall economics of Alpine strawberry cultivation are still unknown, but this could provide another option for growers looking to differentiate their product offerings. Our preliminary study suggests that the red-fruited 'Baron Solemacher' and 'Reine des Vallees' and the white-fruited 'White Delight' and 'White Solemacher' would be the best accessions for initial homeowner and grower trials in southern Florida (Chambers et al. 2018).

\section{Reference}

Chambers, A., P. Moon, Y. Q. Fu, J. Choiseul, J. H. Bai, A. Plotto, and E. Baldwin. 2018. "Yield and Fruit Quality of Sixteen Fragaria vesca Accessions Grown in Southern Florida." Hortscience. 53: 1396-1403. 
Table 1. Yield results during peak fruit production and total yield for each Alpine strawberry tested. Significant differences are shown by a connecting-letters report in parentheses (varieties with the same letter in the parentheses are not consistently different).

\begin{tabular}{|c|c|c|c|c|}
\hline Accession & Average Plot Yield (g) & $\begin{array}{l}\text { Average Plot Fruit } \\
\text { Number }\end{array}$ & $\begin{array}{l}\text { Average Total Plot Yield } \\
\text { (g) }\end{array}$ & $\begin{array}{l}\text { Average Total Plot } \\
\text { Yield (lb) }\end{array}$ \\
\hline Alexandria & $84.0(D-G)$ & $84.6(C-E)$ & $717.5($ A-E) & 1.58 \\
\hline Ali Baba & $34.1(\mathrm{H})$ & $39.8(G)$ & $242.9(E)$ & 0.53 \\
\hline Attila & $49.7(\mathrm{GH})$ & $48.3(\mathrm{FG})$ & $362.5(\mathrm{DE})$ & 0.80 \\
\hline Baron Solemacher & $132.6(\mathrm{AB})$ & $125.1(\mathrm{AB})$ & $1194.5(\mathrm{~A})$ & 2.63 \\
\hline Bowlenzauber & $57.1(\mathrm{~F}-\mathrm{H})$ & $59.8(D-G)$ & 436.7 (C-E) & 0.96 \\
\hline Fragolina di Bosco & $130.8(\mathrm{~A}-\mathrm{C})$ & $139.7(A)$ & $1110.0(A B)$ & 2.44 \\
\hline Golden Alpine & $65.8(\mathrm{E}-\mathrm{H})$ & $61.7(E-G)$ & $558.5(B-E)$ & 1.23 \\
\hline Ivory & $95.3(\mathrm{C}-\mathrm{F})$ & $81.6(D-F)$ & 781.8 (A-E) & 1.72 \\
\hline Mignonette & $88.9(D-F)$ & 94.9 (B-E) & $722.6($ A-E) & 1.59 \\
\hline Pineapple Crush & $31.6(\mathrm{H})$ & $32.8(\mathrm{G})$ & $240.6(E)$ & 0.53 \\
\hline Quattro Stagioni & $64.3(\mathrm{E}-\mathrm{H})$ & $64.4(D-G)$ & 541.5 (B-E) & 1.19 \\
\hline Reine des Vallees & $140.5(\mathrm{~A})$ & $117.6(\mathrm{~A}-\mathrm{C})$ & $1180.1(\mathrm{~A})$ & 2.60 \\
\hline Reugen & $115.3(A-D)$ & $120.8(\mathrm{AB})$ & $1005.7(A-C)$ & 2.21 \\
\hline Semperflorens & 99.6 (B-E) & $98.5(B-D)$ & $874.9(A-D)$ & 1.92 \\
\hline White Delight & $105.7(A-D)$ & $99.6(B-D)$ & $769.3($ A-E) & 1.69 \\
\hline
\end{tabular}

